\title{
DINAMIKA PSIKOLOGIS PEMBELAJARAN BLENDED LEARNING
}

\author{
Alucyana \\ Program Studi Pendidikan Islam Anak Usia Dini, Universitas Islam Riau, Indonesia. \\ e-mail: alucyana@fis.uir.ac.id
}

\begin{abstract}
The Covid-19 pandemic has changed many lines of life, both economic, social and educational. The economic sector suffered massive losses. Several transportation companies were forced to ground their fleets due to this pandemic. In the social sector, there are also social restrictions. The government appeals to the public to limit activities outside the home with the aim of breaking the chain of the spread of Covid 19. Another sector that has also been affected by the Covid19 Pandemic is the world of Education. Distance learning with an online system must be done so that learning continues. One of the learning models used in distance learning is Blended Learning. This learning is considered effective to adjust in this Pandemic period. Even though it is indicated, even though this Pandemic disaster is over, the Blended Learning learning model can still be used, given the increasingly rapid development of technology. It's just that the implementation of the blended learning learning model also leaves problems to be solved. Psychological dynamics occur for teachers, parents and students. The teacher becomes worried whether the learning that the teacher conveys has reached the target for the students. Parents also become anxious, because they are limited in using technology and have to accompany their children while studying. Students also become bored because they have to use electronic media such as cellphones, computers and others every day. This article aims to describe theoretically about Psychological Dynamics in Blended Learning.
\end{abstract}

Keywords: Psychological Dynamics, Learning, Blended Learning

\begin{abstract}
ABSTRAK
Masa Pandemi Covid 19 telah banyak merubah berbagai lini kehidupan, baik Ekonomi, Sosial maupun dunia Pendidikan. Bidang ekonomi terjadi kerugian besaran besaran. Beberapa perusahaan transportasi terpaksa harus mengandangkan armadanya karena terjadinya Pandemi ini. Pada sektor social juga terjadi pembatasan social. Himbauan pemeberintah kepada masyarakat untuk membatasi aktifitas di luar rumah dengan tujuan memutus mata rantai penyebaran Covid 19. Sektor lain yang juga terimabas akibat Pandemi Covid 19 ini adalah dunia Pendidikan. Pembelajaran jarak jauh dengan sistem online terpaksa harus dilakukan agar pembelajaran tetap berjalan. Salah satu model pembelajaran yang digunakan dalam pembelajaran jarak jauh tersebut adalah Pembelajaran Blended Learning. Pembelajaran ini dianggap efektif untuk menyesuaikan dalam masa Pandemi ini. Bahkan di sinyalir, meskipun musibah Pandemi ini berakhir, maka model pemebalajaran Blended Learning ini masih bias di gunakan, mengingat perkembangan tekhnologi yang semakin pesat. Hanya saja pelaksanaan Model pembelajaran blended learning juga menyisakan masalah yang harus diselesaikan. Dinamika Psikologis terjadi bagi Guru, Orangtua dan siswa. Guru menjadi khawatir apakah pembelajaran yang Guru sampaikan sudah mencapai sasaran pada peserta didik. Orangtua juga menjadi cemas, karena keterbatasan mereka menggunakan teknologi dan harus mendampingi anaknya saat belajar. Siswa juga menjadi jenuh karena harus
\end{abstract}


setiap hari menggunakan media elektronik seperti Handphone, Komputer dan lain-lain. Artikel ini bertujuan untuk mendeskripsikan secara teori tentang Dinamika Psikologis dalam Pembelajaran Blended Leraning.

Kata Kunci: Dinamika Psikologis, Pembelajaran, Blended Learning.

\section{PENDAHULUAN}

Hampir dua tahun berlalu, COVID-19 telah melanda sebagian besar negara dan wilayah di dunia. Berdasarkan statistik Organisasi Kesehatan Dunia (WHO), pada 25 Februari 2021, sebanyak 211 negara dan wilayah telah melaporkan kasus yang dikonfirmasi, dan kumulatif jumlah kasus yang dikonfirmasi telah mencapai lebih 112 juta (World Health Organization, 2021). Covid-19 membuat kehidupan manusia lumpuh di berbagai sektor, mulai dari sektor perekonomian sampai dengan sektor pendidikan. Pada sektor ekonomi kita sama sama melihat kerugian besar besaran di bidang ekonomi melanda dunia termasuk di Indonesia. Perusahaan bus antar kota telah mengandangkan hingga $80 \%$ armadanya pada pertengahan Maret 2020. PT KAl membatalkan 44 rute dari Jakarta ke kotakota di Jawa selama bulan April Republika.co.id, 23\&/20).

Demikian pula maskapai penerbangan yang mulai berebut area parkir karena pesawatnya banyak yang tidak dioperasikan. Sementara itu para driver taksi dan taksi online telah mengeluhkan penurunan penumpang hingga $70 \%$ sehingga sebagian besar memilih untuk libur operasi atau pulang kampung. Para driver ojol menyampaikan penurunan jumlah penumpang hingga lebih $80 \%$ (motorplusonline.com).

Pembatasan sosial juga terjadi dimana pemerintah membatasi aktifitas social dan lebih menyarankan untuk bekerja dari rumah. Meskipun pada kenyataannya banyak masyarakat yang tidak mengindahkan anjuran pemerintah ini, masyarakat tetap beraktifitas di luar Rumah, berbagai sektor ekonomi tetap beroperasi, ini tak lain karena mereka harus memenuhi kebutuhan hidup.

Virus ini mulai masuk ke Indonesia sejak awal tahun 2020 dan menyebar secara masif pada Maret 2020. Dari kasuskasus yang muncul pemerintah Indonesia banyak mengambil kebijakan-kebijakan sebagai upaya memutuskan rantai penyebaran COVID-19. Pemerintah memutuskan untuk melakukan lockdown wilayah, penghentian segala aktivitas di luar rumah termasuk proses belajar di sekolah. Terpengaruh oleh pandemi Covid19 seluruh aktivitas siswa di seluruh dunia tidak dapat melaksanakan pembelajaran di sekolah secara normal. Menurut pemantauan Organisasi Pendidikan, IImu Pengetahuan, dan Kebudayaan Perserikatan Bangsa-Bangsa (UNESCO), pada bulan desember, 211 negara telah menerapkan pembelajaran dari rumah secara nasional, yang memengaruhi sekitar 1.575 Miliar siswa yang merupakan $91,3 \%$ dari total jumlah siswa yang terdaftar di seluruh dunia (UNESCO, 2020). Sejalan dengan peringatan dari UNESCO di Indonesia pemerintah Indonesia juga menerapkan Pembelajaran jarak jauh sesuai dengan SE Mendikbud Nomor 4 Tahun 2020. Tentang pelaksanaan Kebijakan Pendidikan dalam Masa Darurat Penyebaran Covid-19, menyatakan bahwa proses belajar dilaksanakan di rumah melalui pembelajaran daring/pembelajaran jarak jauh untuk memberikan pengalaman belajar yang bermakna bagi siswa dengan mempertimbangkan kesenjangan akses/fasilitas belajar di rumah serta tidak lagi memberi penilaian secara kuantitatif namun nilai diberi secara kualitatif sesuai 
dengan perkembangan peserta didik. (Kemdikbud, 2020).

Sistem pembelajaran selama pandemi kini telah berubah mejadi Pembelajaran Jarak Jauh (PJJ). Pembelajaran di dalam kelas yang semula dengan pendekatan tatap muka menjadi tatap maya dengan menggunakan teknologi seperti video conference atau web conference. Begitu juga pembelajaran di luar kelas juga memanfaatkan berbagai kemajuan teknologi. Siswa secara mandiri mencari informasi dengan melihat di televisi atau video, membaca di media cetak maupun online,dan mendengarkan radio atau podcast. Salah satu metode pembelajaran yang dinilai efektif untuk PJJ adalah metode Blended Learning. Sebenarnya, metode ini sudah mulai dirancang dan diterapkan awal abad ke-21. Namun, seiring dengan merebaknya wabah Covid19 , metode yang satu ini dikaji lebih dalam lagi karena dinilai bisa menjadi salah satu metode pembelajaran yang cocok untuk para pelajar di Indonesia. Metode Blended Learning adalah metode yang menggunakan dua pendekatan sekaligus. Dalam artian, metode ini menggunakan sistem daring sekaligus tatap muka maya melalui video conference. Jadi, meskipun pelajar dan pengajar melakukan pembelajaran dari jarak jauh, keduanya masih bisa berinteraksi satu sama lain. Beberapa aplikasi dapat digunakan dalam pembelajaran Blended Learning seperti : Google classroom, teleconference Zoom, Google meet dan lain lain. Selanjutnya Menurut Semler (2005) Blended Learning menggabungkan aspek terbaik dari pembelajaran daring, aktivitas tatap muka terstruktur, dan praktik dunia nyata. Sistem pembelajaran daring, pelatihan di ruang kelas, dan tugas memiliki kelemahan utama. Pendekatan blended learning menggunakan keunggulan masing-masing untuk mengurangi kelemahan yang lainnya. Karakteristik pembelajaran menggunakan blended learning yaitu: 1) pembelajaran yang menggabungkan berbagai cara penyampaian, gaya pembelajaran,model pendidikan, dan beragam media berbasis teknologi; 2)sebagai kombinasi pendidikan langsung (face to face), belajar mandiri, dan belajar secara mandiri secara online; 3) pembelajaran yang didukung oleh kombinasi efektif dari cara penyampaian, pengajaran, dan gaya pembelajaran; 4) pendidik dan orang tua memiliki peranan yang sama pentingnya, dimana pendidik sebagai fasilitator, dan orang tua sebagai pendukung (Prayitno, 2015) Harapannya meskipun pembelajaran tidak dilakukan tatap muka secara langsung, namun diharapkan dengan metode ini, pembelajaran tetap dapat dilaksanakan, namun sayang, dalam pembelajaran dari rumah ini kegiatan belajar mandiri secara daring atau jarak jauh ini tak jarang menimbulkan beberapa masalah, terutama masalah psikologis, baik dari guru, orang tua, maupun siswa itu sendiri.

Dinamika psikologis yang terjadi pada mereka yang melaksanakan pembelajaran jarak jauh dengan metode Blended Learning ini sangat beragam. Dinamika psikologis dapat dipahami sebagai suatu tenaga kekuatan yang terjadi pada diri manusia yang mempengaruhi mental atau psikisnya untuk mengalami perkembangan dan perubahan dalam tingkah lakunya sehari-hari baik itu dalam pikiranya, perasaannya maupun perbuatannya Beberapa mengeluhkan jenuh, cemas serta khawatir atas pelaksanaan pelajaran tersebut. Bagi guru / Dosen mengakhawatirkan apakah materi yang disampaikan saat pembelajaran jarak jauh ini sudah dimengerti siswa, bagi orangtua dengan keterbatasan pemahaman mereka dengan tekhnologi merasa cemas apakah anak anak dapat mengikuti pembelajaran 
secara maksimal, selain itu pada siswa / mahasiswa sendiri, perubahan pembelajaran dari luring menjadi daring membuat mereka jenuh karena harus melakukan adaptasi dengan situasi baru ini di mana mereka setiap hari menggunakan perangkat tekhnologi (Komputer, Handphone) dalam proses pembelajaran. Belum lagi kondisi jaringan internet yang tidak lancer menjadi masalah tersendiri dalam proses pembelajaran tersebut. Kondisi ini diperkuat oleh penelitian yang dilakukan Kumar dan Nayer (2020), selama masa karantina di rumah anakanak mengalami ketakutan (20\%), kecemasan ringan $(21,3 \%)$, kecemasan sedang $(2,7 \%)$, kecemasan berat $(0,9 \%)$, Post Traumatic Stress Symptoms (PTSS) $(2,17 \%)$ dan kehilangan hak untuk keluar rumah serta bersosialisasi dengan teman sebaya $(65,26 \%)$.

Selain kecemasan, dengan pembelajaran jarak jauh dapat mengakibatkan stress pada peserta didik hal ini dapat diakibatkan karena para peserta didik merasa tugas pembelajarannya terasa berat, bosan di rumah terus, proses pembelajaran yang mulai bosan, tidak dapat bertemu dengan teman-teman dan guru secara langsung, keterbatasan sinyal sehingga susah untuk mengikuti pembelajaran online, tidak dapat melakukan hobby dengan leluasa dan tidak bisa melakukan praktek di laboratorium karena ketersediaan alat yang kurang (Livana \& Basthomi, 2020)

Artikel ini bertujuan untuk mendeskripsikan secara teori tentang Dinamika Psikologis dari pembelajaran Blended Learning.

\section{METODE PENELITIAN}

Jenis penelitian yang digunakan adalah studi literatur. Metode studi literatur adalah serangkaian kegiatan yang berkenaan dengan metode pengumpulan data pustaka, membaca dan mencatat, serta mengelolah bahan penelitian (Zed, 2008, dalam Eka Diah Kartiningrum, 2015)

\section{HASIL DAN PEMBAHASAN}

Dari penjelasan diatas dapat penulis sampaikan bahwa Musibah Covid yang melanda dunia memang menimbulkan banyak masalah dari berbagai lini kehidupan. Sebut saja lini ekonomi, sosial termasuk dunia Pendidikan. Sektor Pendidikan seolah "bingung" karena larangan pemerintah untuk tidak berkumpul dalam jumlah yang banyak sehingga pembelajaran pun dilakukan secara online atau Pembelajaran Jarak Jauh (PPJ). Hal ini diperkuat oleh pernyataan Dewi Indah Susanti, dkk (2020) bahwa Sistem pembelajaran selama pandemi kini telah berubah mejadi Pembelajaran Jarak Jauh (PJJ). Pembelajaran di dalam kelas yang semula dengan pendekatan tatap muka menjadi tatap maya dengan menggunakan teknologi seperti video conference atau web conference. Begitu juga pembelajaran di luar kelas juga memanfaatkan berbagai kemajuan teknologi. Siswa secara mandiri mencari informasi dengan melihat di televisi atau video, membaca di media cetak maupun online, dan mendengarkan radio atau podcast. Salah satu model Pembelajaran Jarak Jauh (PPJ).

Keberhasilan pembelajaran ditentukan oleh berbagai faktor diantaranya guru. Guru dalam melaksanakan proses pembelajaran perlu melakukan berbagai persiapan dan pemilihan perangkat pembelajaran agar peserta didik dapat memahami materi dengan mudah, pembelajaran menyenangkan, peserta didik aktif dan saling interaktif. Untuk itu perlu upaya guru memilih berbagai macam strategi, metode dan model pembelajaran inovatif yang dapat memenuhi kebutuhan peserta didik. Beberapa model 
pembelajaran inovatif antara lain: Model Kooperatif Tipe Make A Match, Discovery Learning ,Think Pair Share, Student Teams Achievement Division , Flipped dan Blended Learning (Setiawan et al., 2019).

Model pembelajaran Blended Learning merupakan model pembelajaran yang mengintegrasikan teknologi dalam proses pembelajaran. Di Indonesia khususnya Sekolah Dasar Model Blended Learning masih jarang digunakan oleh Sebagian besar guru. Berdasarkan hasil penelitian awal (Widyaningsih et al., 2020) 12 guru dari berbagai sekolah yang berbeda di sekolah dasar yang berstatus PNS belum pernah melaksanakan pembelajaran Blended Learning karena tidak mengetahui adanya model pembelajaran tersebut. Wawasan guru yang kurang luas dapat menyebabkan Pendidikan tidak berjalan dengan baik sesuai tuntutan pembelajaran di masa depan. Akibatnya Anak didik menjadi tidak siap dalam menghadapi permasalahan dan tuntutan perkembangan zaman.

Selanjutnya pembelajaran yang dinilai efektif untuk PJJ adalah metode Blended Learning. Metode ini merupakan gabungan 2 istilah Bahasa Inggris, yaitu: blended dan learning. Kata blend artinya campuran, sedangkan learn artinya belajar. Secara sederhana blended learning dapat dimaknai dengan belajar campuran. Sehingga metode pembelajaran ini mengunakan berbagai macam cara. Istilah blended learning disepakati oleh para ahli merupakan perpaduan pembelajaran secara konvensional dan daring. Pembelajaran blended learning dipilih karena menjadi satusatunya media penyampaian materi antara guru dan siswa dalam masa darurat pandemi. Di sinyalir meskipun Pandemi telah berakhir, pembelajaran model Blended Laerning tetap digunakan, karena seriring perkembangan tekhnologi, maka pembelajaran Blended Learning dianggap sesuai dengan perkembangan zaman.

Meskipun demikian pelaksanaan pembelajaran Blended tentu tidak semudah yang di bayangkan. Beragam Dinamika Psikologis akan dirasakan baik oleh guru/ Dosen, Orangtua, siswa / mahasiswa dalam menjalaninya. Perasaan cemas, khawatir serta jenuh akan dirasakan dalam pembelajaran tersebut. Ditutupnya proses pembelajaran secara langsung dan sekolah memberlakukan pembelajaran jarak jauh dapat mengakibatkan stress dan depresi pada anak dan remaja, hal ini disebabkan karena anak dan remaja merasa kesepian tidak dapat berhubungan dengan teman sebaya sehingga mereka lebih banyak menggunakan media social untuk berinteraksi, kurangnya aktivitas fisik di luar dan menghkhawatirkan tentang tugas sekolahnya. Meskipun waktu dengan keluarga lebih banyak tetapi bagi anak dan remaja tetap membutuhkan waktu untuk berhubungan dengan teman (Ellis et al., 2020). Meskipun demikian seriing pembiasaan diharapkan kondisi psikologis yang tidak diinginkan akan dapat di atasi. Hal ini di asumsikan para guru, orangtua serta siswa sudah dapat menyesuaikan pembelajaran blended learning tersebut.

\section{SIMPULAN}

Dari pemaparan di atas dapat disimpulkan bahwa masa pandemi membuat semua keadaan mengalami perubahan, termasuk perubahan dalam model pembelajaran. Salah satu model pembelajaran yang diasumsikan akan tetap digunakan meskipun masa Pandemi telah berakhir adalah Model Pembelajaran Blended Learning. Model ini dianggap paling sesuai dengan perkembangan tekhnologi yang terus mengalami perubahan. Meskipun dalam pelaksanaan model pembelajaran blended learning akan menemukan 
beragam dinamika psikologis bagi yang menjalaninya yakni Guru, siswa dan Orangtua namun seriring pembiasaan, maka model pembelajaran blended learning akan dapat digunakan dengan baik.

\section{DAFTAR PUSTAKA}

Ellis, W. E., Dumas, T. M., \& Forbes, L. M. (2020). Physically isolated but socially connected: Psychological adjustment and stress among adolescents during the initial COVID-19 crisis. Canadian Journal of Behavioural Science/Revue canadienne des sciences du comportement, 52(3), 177-187. DOI: https://doi.org/10.1037/ cbs0000215

Kartiningrum, E. D. (2015). Panduan Penyusunan Studi Literatur. Mojokerto: LPPM Poltekes Majapahit.

Kemdikbud, \& Kemdikbud, pengelola web. (2020). Pedoman Penyelenggaraan Belajar dari Rumah. In Jakarta, 28 Mei 2020.

Livana, M., \& Basthomi, Y. (2020). Penyebab Stres Mahasiswa Selama Pandemi Covid-19. Jurnsl IImu Keperawatan Jiwa, 3(2), 203-208.

Prayitno, W. (2015). Implementasi Blended Learning dalam Pembelajaran pada Pendidikan Sekolah Dasar dan Menengah. Jurnal Pendidikan, 6(01).
Republika Online, (2020, 29 Maret). Covid19 Terus Meningkat, KAI Batalkan 28 KA Jarak Jauh. [Online] Tersedia: (29 Maret 2020/)

Semler, S. (2005). Use blended learning to increase learner engagement and reduce training cost. (On-line) dalam http://www. learningsim. com/content/lsnews/blended_learning1. html. Diunduh, 11.

Setiawan, N. H. A., \& Abdulkarim, A. (2019). Application of Board Game Pancasila Dadu (Pandu) in Civic Learning. In Annual Civic Education Conference (Vol. 418, pp. 467-470).

Susanti, D. I., \& Prameswari, J. Y. (2020). Adaptasi Blended Learning di Masa Pandemi COVID-19 untuk Pembelajaran Bahasa Inggris di Sekolah Dasar. Lingua Susastra, 1(2), 50-61.

UNESCO. (2020). Covid-19 Education: From disruption to recovery. Unesco.

Widyaningsih, S. W., Yusuf, I., Prasetyo, Z. K., \& Istiyono, E. (2020). Online interactive multimedia oriented to HOTS through e-learning on physics material about electrical circuit. JPI (Jurnal Pendidikan Indonesia), 9(1), 1-14.

World Health Organization. (2021). WHO Coronavirus Disease 2019 (COVID19) Dashboard. WHO.Int. 